\title{
ANALISIS LQ DAN ANALISIS SHIFT- SHARE DALAM PEMANFAATAN EKONOMI SEKTORAL KABUPATEN MALUKU TENGAH TAHUN 2008 - 2010
}

$L Q$ and Shift-Share Analysis in Sectoral Economic Utilization of Central Moluccas Regency

at the 2008 - 2010

\author{
JEFRI TIPKA \\ Badan Pusat Statistik Kabupaten Maluku Tengah \\ Jl. R. A. Kartini No. 15 Kelurahan Namaelo, Masohi 97511 \\ E-mail : jefri.tipka@bps.go.id
}

\begin{abstract}
ABSTRAK
PDRB merupakan Indikator Ekonomi Makro yang dapat diturunkan untuk menghitung indikatorindikator penting lainnya seperti Pertumbuhan Ekonomi, PDRB Per Kapita, Pendapatan Per Kapita dan sebagainya. Selain itu, PDRB dapat digunakan untuk berbagai analisis. Analisis terhadap PDRB sangat penting salah satunya untuk melihat potensi dan keunggulan apa saja yang dimiliki oleh Kecamatan tertentu. Sektor apa yang dapat menyumbangkan nilai tambah yang besar terhadap perekonomian. Selain melihat potensi ekonomi analisis terhadap PDRB juga dapat dilihat untuk melihat ketimpangan Ekonomi antar daerah/Kecamatan.

Hal ini bisa digunakan sebagai salah satu evaluasi dalam kebijakan yang telah dilakukan dan sebagai pertimbangan untuk mengmbil kebijakan yang paling tepat dimasa yang akan datang. Salah satu metode yang populer untuk menganalisis potensi ekonomi suatu daerah/Kecamatan adalah metode Location Quoetient (LQ). Sedangkan untuk melihat/mengukur ketimpangan pembangunan antar daerah secara sederhana dapat dilakukan dengan menggunakan analisis shift-share.
\end{abstract}

Kata kunci: Location Quontinent (LQ), Shift-share, PDRB

\section{PENDAHULUAN}

Pengertian Produk Domestik Regional Bruto (PDRB) dapat ditinjau pada 3 (tiga) segi, yaitu Pendekatan Produksi, Pendapatan dan Pengeluaran. Jika ditinjau dengan pendekatan produksi, maka Produk Domestik Regional Bruto (PDRB) merupakan jumlah nilai produk barang dan jasa akhir yang dihasilkan oleh unit produksi didalam suatu daerah/region dalam jangka waktu tertentu (biasanya 1 tahun).

Unit produksi atau yang lebih dikenal dengan lapangan usaha/sektor ekonomi dalam penyajiannya dikelompokkan kedalam 9 (sembilan) lapangan usaha/sektor ekonomi yaitu :

1. Sektor Pertanian

Sektor ini mencakup Sub Sektor Tanaman Bahan Makanan, Perkebunan, Peternakan dan hasil-hasilnya, kehutanan dan Perikanan.

2. Sektor Pertambangan dan Penggalian

3. Sektor Industri Pengolahan

4. Sektor Listrik, Gas dan Air Bersih

5. Sektor Bangunan
6. Sektor Perdagangan, Hotel dan Restoran

7. Sektor Pengangkutan \& Komunikasi

8. Sektor Keuangan, Persewaan, dan Jasa Perusahaan

9. Sektor Jasa-jasa

Dengan menggunakan pendekatan Pendapatan, maka Produk Domestik Regional Bruto (PDRB) dapat diartikan sebagai jumlah/total balas jasa yang diterima oleh faktor-faktor produksi yang ikut serta dalam proses produksi disuatu daerah/region dalam jangka waktu tertentu (biasanya 1 tahun).

Dengan pendekatan pengeluaran Produk Domestik Regional Bruto (PDRB) diartikan sebagai jumlah/total pengeluaran/penggunaan yang mencakup Konsumsi Rumah Tangga, Konsumsi Lembaga Swasta tidak mencari keuntungan (Lembaga Nirlaba), Konsumsi Pemerintah/Governant Expenditure, Pembentukan Modal Tetap Bruto (PMTB), Ekspor Netto (Ekspor dikurangi Impor) dan perubahan stok didalam suatu daerah/region dalam jangka waktu tertentu (biasanya selama satu tahun).

PDRB merupakan Indikator Ekonomi Makro yang dapat diturunkan untuk menghitung indikator-indikator penting lainnya seperti Pertumbuhan Ekonomi, PDRB Per 
Kapita, Pendapatan Per Kapita dan sebagainya. Selain itu dapat digunakan untuk berbagai analisis.

Analisis terhadap PDRB sangat penting salah satunya untuk melihat potensi dan keunggulan apa saja yang dimiliki oleh kabupaten/kota tertentu. Sektor apa yang dapat menyumbangkan nilai tambah yang besar terhadap pererkonomian. Selain melihat potensi ekonomi analisis terhadap PDRB juga dapat dilihat untuk melihat ketimpangan Ekonomi antar daerah/kabupaten. Hal ini bisa digunakan sebagai salah satu evaluasi dalam kebijakan yang telah dilakukan dan sebagai pertimbangan untuk mengmbil kebijakan yang paling tepat dimasa yang akan datang. Salah satu metode yang populaer untuk menganalisis potensi ekonomi suatu daerah/kabupaten adalah metode Location Quoetient (LQ). Sedangkan untuk melihat/mengukur ketimpangan pembangunan antar daerah secara sederhana dapat dilakukan dengan menggunakan analisis shift-share.

Data PDRB Kecamatan di Kabupaten Maluku Tengah dapat diperoleh dari Publikasi Produk Domestik Regional Bruto (PDRB) Kabupaten Maluku Tengah yang diterbitkan tahunan. Dalam tulisan ini data yang digunakan adalah data PDRB Kecamatan di Maluku Tengah dengan periode waktu tahun 2008-2010.

\section{METODE PENELITIAN}

\section{Analisis Location Quoetient (LQ)}

Analisis Location Quotient (LQ) adalah salah satu analisis yang dapat digunakan untuk menganalisis potensi suatu daerah secara sektoral. Dari Analisis ini dapat diketahui sektor unggulan suatu daerah tertentu. Rumus untuk menghitung nilai Location Quotient (LQ) untuk sektor $I$ di region $r$ (dimana $r$ adalah bagian dari $n$ ) adalah sebagai berikut :

sektor $I$ di region $r$ (dimana $r$ adalah bagian dari $n$ ) adalah sebagai berikut :

$$
L Q_{i}=\frac{\left(X_{i}^{r} / X_{r}\right)}{\left(X_{i}^{n} / X_{n}\right)}
$$

$X_{i}^{r}=$ Nilai tambah sektor $I$ di region $\mathrm{r}$

$X_{r}=$ Nilai tambah total diregion $r$

$X_{i}^{n}=$ Nilai tambah sektor $I$ di region $n$

$X_{n}=$ Nilai tambah total di region $n$

$\checkmark$ Jika nilai $L Q<1$, maka dapat dikatakan bahwa sektor tersebut secara relatif kurang memiliki keunggulan komparatif.

$\checkmark$ Jika nilai $L Q=1$, maka dapat dikatakan bahwa daerah yang bersangkutan tidak terspesialisasi secara berlebihan ataupun kurang pada aktivitas ekonomi yang dimaksud.

$\checkmark \quad$ Jika nilai $L Q>1$, maka dapat dikatakan bahwa daerah tersebut relatif terspesialisasi secara berlebihan (overspecialized) pada aktivitas ekonomi (sektor) yang bersangkutan.

\section{Analisis Shift-Share}

Analisis shift-share adalah salah satu analisis yang sederhana dengan menggunakan konsep proporsi dan pertumbuhan dimana kita dapat melihat sektor-sektor apa saja disuatu daerah yang lebih unggul dibandingkan daerah yang lain.

Dengan menggunakan perhitungan shift-share akan memungkinkan dihasilkannya perhitungan antar waktu (pertumbuhan) yang melibatkan daerah/negara lain (dengan penghitungan yang sederhana). Penghitungan dengan menggunakan analisis shift share mengasumsikan bahwa perekonomian daerah (semisal Kota Ambon) dipengaruhi oleh perekonomian Maluku dan kabupaten lain (keterkaitan antar daerah dan pengaruh kebijakan ekonomi provinsi).

Pertumbuhan kegiatan disuatu daerah pada dasarnya ditentukan oleh 3 (tiga) hal :

1. National Share/National Growth Effect $(N)$

National Share/National Growth Effect $(N)$ merupakan pertumbuhan daerah dibandingkan dengan prtumbuhan provinsi dari provinsi tertentu.

$\checkmark$ Jika sektor tertentu pada provinsi tersebut memiliki pertumbuhan yang positif maka Nilai $N$ untuk daerah objek yang dianalisis akan positif.

$\checkmark$ Jika sektor tertentu negara tersebut memiliki pertumbuhan negatif maka nilai $N$ untuk daerah objek yang dianalisis akan negatif juga.

2. Proportional Shift/Sectoral Mix Effect/Composition Shift $(M)$

Proportional Shift/Sectoral Mix Effect/Composition Shift $(M)$ adalah merupakan efek dari perbedaan pertumbuhan sektoral yang diamati pada suatu provinsi pembanding terhadap pertumbuhan total provinsi tersebut.

$\checkmark$ Jika sektor yang dibandingkan tumbuh lebih tinggi daripada pertumbuhan total pertumbuhan di provinsi pembanding maka hasilnya akan positif sehingga nilai $M$ untuk sektor tersebut didaerah objek yang diteliti akan menjadi positif.

$\checkmark$ Jika sektor yang dibandingkan tumbuh lebih rendah daripada pertumbuhan total pertumbuhan di provinsi pembanding maka hasilnya akan negatif sehingga nilai $M$ untuk sektor tersebut didaerah objek yang diteliti akan menjadi negatif.

3. Regional Share/Competitive Effect $(R)$

Regional Share/Competitive Effect
menggambarkan bagaimana jika sektor didaerah objek tersebut tumbuh seperti pola pertumbuhan sektor yang sama di provinsi pembanding.

$\checkmark$ Jika hasil $R$ adalah positif dan lebih kecil dari pertumbuhan aktual sektor tersebut didaerah objek yang diteliti maka secara relatif provinsi pembanding lebih unggul dari daerah objek yang bersangkutan.

$\checkmark$ Jika hasil $R$ adalah positif dan lebih besar dari pertumbuhan aktual sektor tersebut didaerah objek yang diteliti maka secara relatif daerah objek yang diteliti/bersangkutan lebih baik daripada provinsi pembanding.

$\checkmark$ Jika hasil $R$ adalah negatif maka dapat dikatakan provinsi pembanding adalah lebih unggul secara 
absolut pada sektor yang bersangkutan dibandingkan dengan daerah objek yang diamati.

Secara kuantitatif, perumusan shift-share harus memiliki keteraturan penghitungan sebagai berikut :

$$
G=R+N+M
$$

(formula ini dapat digunakan untuk mencek kebenaran dari perhitungan analisis shift-share).

Dimana $G=$ Normal Growth

$$
\begin{aligned}
R= & \text { Regional Share/Competitive Effect } \\
N= & \text { National Share/National Growth Effect } \\
M= & \text { Proportional Shift/Sectoral Mix Effect/ } \\
& \text { Composition Shift }
\end{aligned}
$$

Normal Growth $(G)$ adalah pertumbuhan disetiap sektor yang dinyatakan dalam angka nominal dan bukan persentase. Normal Growth bisa bernilai positif dan bernilai negatif. Jika hasilnya positif maka sektor tersebut tumbuh, sedangkan jika nilainya negatif maka sektor tersebut dapat dikatakan tidak tumbuh.

Adapun rumus untuk melakukan penghitungan $R, N$, $M$ secara matematik adalah sebagai berikut :

$$
\begin{aligned}
& R=\left[X_{\text {irt }}-\left(\frac{X_{\text {int }}}{X_{\text {ino }}}\right) \cdot X_{\text {iro }}\right] \\
& N=\left[X_{\text {iro }} \cdot\left(\frac{X_{n t}}{X_{n o}}\right)-X_{\text {iro }}\right] \\
& M=\left[\left(\frac{X_{\text {int }}}{X_{\text {ino }}}\right)-\left(\frac{X_{n t}}{X_{n o}}\right)\right] \cdot X_{\text {iro }}
\end{aligned}
$$

Dimana :

$X=$ Data statistik yang digunakan berupa tenaga kerja, input ataupun output

$n=$ Nasional

$r=$ Regional

$i=$ Sektor

$t=$ Menunjukkan tahun akhir

$o=$ Menunjukkan tahun awal

Apabila perhitungan shift-share benar naka nilai $R+N+M=G$ untuk setiap sektor, dimana $G$ adalah selisih nilai tambah sektor tertentu pada waktu $t 1-t 0$.

\section{HASIL DAN PEMBAHASAN}

\section{A. Analisis Location Quoetient (LQ) \\ $L Q$ Sektor Pertanian}

Grafik 1 menunjukkan Nilai Tambah Sektor Pertanian menurut Kecamatan di Kabupaten Maluku Tengah. Sektor Pertanian merupakan sektor yang mendominasi perekonomian Kabupaten Maluku Tengah karena pada tahun 2008-2010 kurang lebih 30\% perekonomian Kabupaten Maluku Tengah disumbang oleh sektor ini.

Ditinjau dari nilai LQ dapat dilihat bahwa nilai LQ tahun 2008-2010 tidak jauh berubah (Lihat Tabel 1). Sembilan dairi empat belas kecamatan di Kabupaten Maluku Tengah memiliki nilai LQ sektor pertanian lebih besar dari 1, sedangkan 5 kecamatan yakni kecamatan kota masohi, kecamatan saparua, kecamatan salahutu, kecamatan leihitu dan kecamatan leihitu barat memiliki nilai LQ yang lebih kecil dari 1. Ini dapat diartikan bahwa sektor pertanian merupakan salah satu sektor unggulan di Kabupaten Maluku Tengah karena mayoritas kecamatan memiliki nilai LQ lebih dari 1.

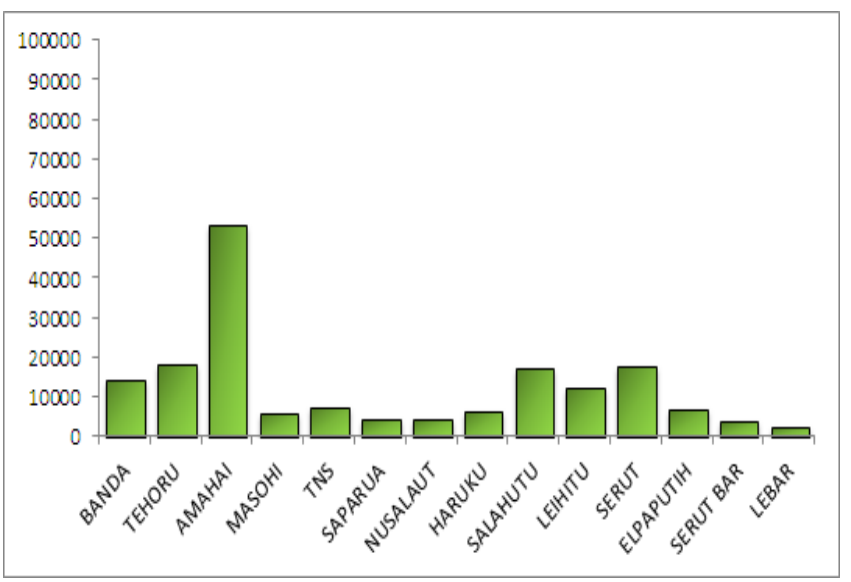

Sumber: BPS Kabupaten Maluku Tengah, 2011

Gambar 1. Nilai Tambah Sektor Pertanian Menurut Kecamatan di Kabupaten Maluku Tengah Tahun 2010 (Juta Rupiah)

Tabel 1. Nilai LQ Sektor Pertanian Menurut Kecamatan di Kabupaten Maluku Tengah Tahun $2008-2010$

\begin{tabular}{lccc}
\hline \multicolumn{1}{c}{ Kecamatan } & $\mathbf{2 0 0 8}$ & $\mathbf{2 0 0 9}$ & $\mathbf{2 0 1 0}$ \\
\hline Banda & 1,41 & 1,42 & 1,40 \\
Tehoru & 1,66 & 1,67 & 1,69 \\
Amahai & 1,65 & 1,70 & 1,69 \\
Kota Masohi & 0,14 & 0,14 & 0,14 \\
TNS & 1,71 & 1,72 & 1,73 \\
Saparua & 0,45 & 0,44 & 0,44 \\
Nusalaut & 1,67 & 1,68 & 1,71 \\
Pulau Haruku & 1,05 & 1,07 & 1,09 \\
Salahutu & 0,80 & 0,78 & 0,79 \\
Leihitu & 0,89 & 0,89 & 0,93 \\
Seram Utara & 1,41 & 1,41 & 1,40 \\
Teluk Elpaputih & 1,29 & 1,30 & 1,33 \\
Seram Utara Barat & 1,45 & 1,48 & 1,55 \\
Leihitu Barat & 0,93 & 0,94 & 0,97 \\
\hline
\end{tabular}

Sumber : Data BPS Diolah

Nilai LQ tertinggi pada tahun 2010 adalah Kecamatan TNS, Kemudian Kecamatan Nusalaut selanjutnya disusul oleh Kecamatan Tehoru dan Kecamatan Amahai. Jika dilihat dari tabel pergeseran nilai LQ mulai terjadi pada tahun 2010 dimana Kecamatan Amahai memiliki nilai LQ lebih besar dari Kecamatan Nusalaut di tahun sebelumnya berubah sebaliknya di tahun 2010. Kecamatan Kota Masohi memiliki nilai LQ yang terendah selama periode 20082010. 


\section{$L Q$ Sektor Pertambangan dan Penggalian}

Gambar 2 Nilai Tambah Bruto Sektor Pertambangan dan Penggalian Kecamatan di Kabupaten Maluku Tengah menunjukan bahwa sektor ini didominasikan oleh Kecamatan Amahai, Kecamatan Leihitu, dan Kecamatan Leihitu Barat. Sedangkan Kecamatan lain hanya memiliki Nilai Tambah Bruto Sektor Pertambangan dan Penggalian jauh dibawah ketiga Kecamatan tersebut. Ini disebabkan karena kegiatan/subsektor penggalian banyak tersebar di Kecamatan tersebut.

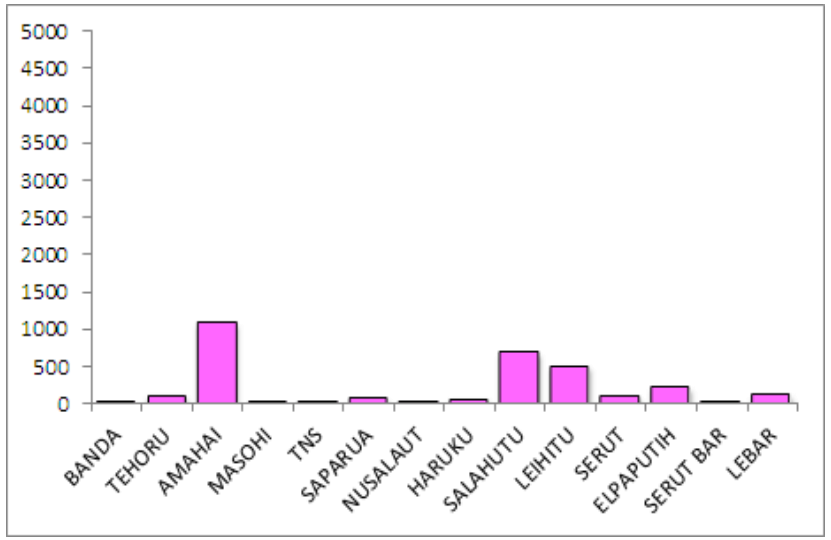

Sumber: BPS Kabupaten Maluku Tengah, 2011

Gambar 2. Nilai Tambah Sektor Pertambangan dan Penggalian Menurut Kecamatan di Kabupaten Maluku Tengah Tahun 2010 (Juta Rupiah)

Tabel 2. Nilai LQ Sektor Pertambangan \& Penggalian Menurut Kecamatan di Kabupaten Maluku Tengah Tahun 2008 - 2010

\begin{tabular}{llll}
\hline \multicolumn{1}{c}{ Kecamatan } & $\mathbf{2 0 0 8}$ & $\mathbf{2 0 0 9}$ & $\mathbf{2 0 1 0}$ \\
\hline Banda & 0,17 & 0,16 & 0,17 \\
Tehoru & 0,61 & 0,61 & 0,60 \\
Amahai & 1,78 & 1,88 & 1,96 \\
Kota Masohi & 0,00 & 0,00 & 0,01 \\
TNS & 0,26 & 0,26 & 0,26 \\
Saparua & 0,47 & 0,45 & 0,43 \\
Nusalaut & 0,11 & 0,11 & 0,11 \\
Pulau Haruku & 0,60 & 0,61 & 0,62 \\
Salahutu & 1,92 & 1,86 & 1,81 \\
Leihitu & 2,23 & 2,18 & 2,20 \\
Seram Utara & 0,46 & 0,47 & 0,47 \\
Teluk Elpaputih & 1,55 & 1,49 & 1,45 \\
Seram Utara Barat & 0,53 & 0,54 & 0,55 \\
Leihitu Barat & 2,50 & 2,51 & 2,54 \\
\hline
\end{tabular}

Sumber : Data BPS Diolah

Dari tabel LQ sektor Pertambangan dan Penggalian terlihat dengan jelas bahwa terdapat 5 Kecamatan yang memiliki nilai LQ > 1; diantaranya Kecamatan Amahai, Kecamatan Salahutu, Kecamatan Leihitu, Kecamatan Teluk Elpaputih, dan Kecamatan Leihitu Barat. Nilai LQ dari Kecamatan-Kecamatan relatif tidak konsisten dari tahun 2008-2010, dapat dilihat pada Kecamatan Leihitu
Nilai LQ pada tahun 2008 sebesar 2,23 mengalami penurunan di tahun 2009 menjadi 2,18 selanjutnya pada tahun 2010 mengalami kenaikan menjadi 2,20; kondisi serupa juga terjadi pada beberapa kecamatan yang lain.

Hal lain yang menarik adalah hampir 64,28 persen Kecamatan di Kabupaten Maluku Tengah memiliki nilai LQ $<1$, sehingga dapat dikatakan bahwa Kabupaten Maluku Tengah tidak terspesialisasi secara berlebihan ataupun kurang pada Sektor Pertambangan dan Penggalian.

\section{$L Q$ Sektor Industri Pengolahan}

Sektor Industri Pengolahan merupakan sektor sekunder dalam suatu perekonomian. Dari Grafik Nilai Tambah Bruto Sektor Industri Pengolahan dapat diketahui bahwa sektor ini relatif ada pada sebagian besar Kecamatan. Nilai Tambah terbesar dari sektor ini disumbangkan dari Kecamatan Leihitu, sedangkan Nilai Tambah yang terkecil disumbangkan dari Kecamatan Seram Utara Barat. Secara Keseluruhan Sektor Industri Pengolahan Menyumbangkan 10,64 persen pada total PDRB Kabupaten Maluku Tengah tahun 2010.

Nilai LQ Sektor Industri Pengolahan pada Kecamatan-Kecamatan di Kabupaten Maluku Tengah cenderung berfriasi dari tahun ke tahun. Hampir 50 persen Kecamatan yang ada di kabupaten Maluku Tengah memiliki nilai LQ > 1, diantaranya : Kecamatan Banda, Kecamatan TNS, Kecamatan Saparua, Kecamatan Nusalaut, Kecamatan Pulau Haruku, Kecamatan Salahutu dan Kecamatan Leihitu.

Nilai LQ Sektor Industri Pengolahan 7 Kecamatan di Kabupaten Maluku Tengah berada diatas satu dan sisanya sebaliknya, sehingga dapat dikatakan bahwa Sektor Industri Pengolahan merupakan salah satu sektor unggulan di Kabupaten Maluku Tengah.

Tabel 3. Nilai LQ Sektor Industri Pengolahan Menurut Kecamatan di Kabupaten Maluku Tengah Tahun 2008 - 2010

\begin{tabular}{lccc}
\hline \multicolumn{1}{c}{ Kecamatan } & $\mathbf{2 0 0 8}$ & $\mathbf{2 0 0 9}$ & $\mathbf{2 0 1 0}$ \\
\hline Banda & 1,63 & 1,55 & 1,45 \\
Tehoru & 0,66 & 0,64 & 0,63 \\
Amahai & 0,93 & 0,87 & 0,82 \\
Kota Masohi & 0,44 & 0,48 & 0,53 \\
TNS & 1,07 & 1,03 & 1,08 \\
Saparua & 1,90 & 1,88 & 1,88 \\
Nusalaut & 1,54 & 1,51 & 1,50 \\
Pulau Haruku & 1,62 & 1,54 & 1,49 \\
Salahutu & 0,82 & 0,93 & 1,06 \\
Leihitu & 2,63 & 2,64 & 2,57 \\
Seram Utara & 0,90 & 0,90 & 0,89 \\
Teluk Elpaputih & 0,11 & 0,11 & 0,10 \\
Seram Utara Barat & 0,04 & 0,04 & 0,04 \\
Leihitu Barat & 0,23 & 0,23 & 0,22 \\
\hline
\end{tabular}

Sumber : Data BPS Diolah

Sedangkan Kecamatan yang memiliki nilai $\mathrm{LQ}<1$, diantranya Kecamatan Tehoru, Kecamatan Amahai, 
Kecamatan Kota Masohi, Kecamatan Seram Utara, Kecamatan Teluk Elpaputih, Kecamatan Seram Utara Barat dan Kecamatan Leihitu Barat. Kecamatan yang memiliki nilai LQ yang terendah pada Sektor Industri Pengolahan adalah Kecamatan Seram Utara Barat dan Kecamatan Leihitu barat yang berturut-turut sebesar 0,04 dan 0,22 .

\section{$L Q$ Sektor Listrik dan Air Bersih}

Dari Tabel 4 dapat dilihat bahwa Kecamatan yang relatif memiliki keunggulan pada sektor ini hanya 3 Kecamatan diantaranya Kecamatan Amahai, Kecamatan Kota Masohi dan Kecamatan Salahutu. Sedangkan Kecamatan lainnya tidak memiliki keunggulan karena nilai LQnya berada di bawah 1.

Nilai LQ tertinggi pada Sektor Listrik dan Air Bersih dari tahun 2008 - 2010 adalah Kecamatan Kota Masohi berturut-turut sebesar 1,71; 1,70 dan 1,66. Ini dikarenakan Kecamatan Kota Masohi merupakan daerah Perkotaan sekaligus merupakan Ibu Kota Kabupaten Maluku Tengah, dengan kata lain Kecamatan Kota Masohi terspesialisasi secara lebih pada sektor ini.

Tabel 4. Nilai LQ Sektor Listrik dan Air Bersih Menurut Kecamatan di Kabupaten Maluku Tengah Tahun 2008 - 2010

\begin{tabular}{lccc}
\hline \multicolumn{1}{c}{ Kecamatan } & $\mathbf{2 0 0 8}$ & $\mathbf{2 0 0 9}$ & $\mathbf{2 0 1 0}$ \\
\hline Banda & 0,28 & 0,26 & 0,27 \\
Tehoru & 0,34 & 0,33 & 0,34 \\
Amahai & 1,14 & 1,15 & 1,15 \\
Kota Masohi & 1,71 & 1,70 & 1,66 \\
TNS & 0,64 & 0,61 & 0,62 \\
Saparua & 0,93 & 0,94 & 0,94 \\
Nusalaut & 0,43 & 0,42 & 0,42 \\
Pulau Haruku & 0,62 & 0,62 & 0,65 \\
Salahutu & 1,18 & 1,19 & 1,19 \\
Leihitu & 0,91 & 0,89 & 0,91 \\
Seram Utara & 0,61 & 0,59 & 0,58 \\
Teluk Elpaputih & 0,07 & 0,06 & 0,06 \\
Seram Utara Barat & 0,30 & 0,28 & 0,26 \\
Leihitu Barat & 0,71 & 0,71 & 0,72 \\
\hline
\end{tabular}

Sumber : Data BPS Diolah

\section{$L Q$ Sektor Bangunan}

Ditinjau dari besarnya nilai LQ Sektor Bangunan maka Kecamatan di Kabupaten Maluku Tengah terbagi atas tiga kelompok yaitu :

- Kelompok yang memiliki nilai LQ $<1$, Kecamatan yang termasuk dalam kelompok ini adalah Kecamatan Banda, Kecamatan Tehoru, Kecamatan Amahai, Kecamatan TNS, Kecamatan Saparua, Kecamatan Saparua, Kecamatan Nusalaut, Kecamatan Pulau Haruku, Kecamatan Salahutu, Kecamatan Leihitu, Kecamatan Seram Utara, Kecamatan Teluk Elpaputih, Kecamatan Seram Utara Barat dan Kecamatan Leihitu Barat (Pada tahun 2008-2010). Ini berarti bahwa Kecamatan tersebut relatif tidak memiliki nilai komparatif/keunggulan komparatif pada Sektor Bangunan.

- Kelompok yang memiliki nilai $\mathrm{LQ}=1$. Jika nilai $\mathrm{LQ}$ suatu daerah sebesar 1 maka dapat dikatakan bahwa daerah yang bersangkutan tidak terspesialisasi secara berlebihan ataupun kurang pada aktivitas ekonomi yang dimaksud. Selama tahun 2008-2010 tidak ada satu pun Kecamatan yang termasuk dalam kelompok ini.

- Kelompok yang memiliki nilai LQ > 1. Kecamatan yang memiliki nilai LQ $>1$ adalah Kecamatan Kota Masohi. Kecamatan yang termasuk dalam kategori ini dapat dikatakan bahwa Kecamatan tersebut adalah Kecamatan yang relatif terspesialisasi secara berlebihan (overspecialized) pada aktivitas ekonomi (sektor) yang bersangkutan. Atau dapat juga dikatakan bahwa daerah tersebut memiliki keunggulan pada Sektor Bangunan.

Tabel 5. Nilai LQ Sektor Bangunan Menurut Kecamatan di Kabupaten Maluku Tengah Tahun $2008-2010$

\begin{tabular}{llll}
\hline \multicolumn{1}{c}{ Kecamatan } & $\mathbf{2 0 0 8}$ & $\mathbf{2 0 0 9}$ & $\mathbf{2 0 1 0}$ \\
\hline Banda & 0,67 & 0,64 & 0,65 \\
Tehoru & 0,62 & 0,62 & 0,60 \\
Amahai & 0,84 & 0,87 & 0,85 \\
Kota Masohi & 2,27 & 2,28 & 2,31 \\
TNS & 0,38 & 0,36 & 0,35 \\
Saparua & 0,83 & 0,78 & 0,74 \\
Nusalaut & 0,45 & 0,44 & 0,42 \\
Pulau Haruku & 0,78 & 0,74 & 0,71 \\
Salahutu & 0,45 & 0,42 & 0,40 \\
Leihitu & 0,50 & 0,46 & 0,44 \\
Seram Utara & 0,92 & 0,87 & 0,80 \\
Teluk Elpaputih & 0,05 & 0,05 & 0,04 \\
Seram Utara Barat & 0,02 & 0,02 & 0,03 \\
Leihitu Barat & 0,04 & 0,04 & 0,04 \\
\hline Sumber : Data BPS Diolah & & &
\end{tabular}

\section{$L Q$ Sektor Perdagangan, Hotel dan Restoran}

Jika dilihat dari nilai LQ dapat diketahui bahwa meskipun Sektor Perdagangan, Hotel dan Restoran didominasi Kecamatan Kota Masohi dan Kecamatan Salahutu, ternyata tidak berarti bahwa Kecamatan Kota Masohi dan Kecamatan Salahutu hanya sendiri yang memiliki Keunggulan Komparatif atau terspesialisasi secara berlebihan pada sektor ini, juga terdapat beberapa Kecamatan Lain. Hal ini dapat dilihat dengan nilai LQ dari beberapa Kecamatan lain yang lebih besar dari 1, diantaranya : Kecamatan saparua Kecamatan Pulau Haruku, Kecamatan Leihitu, Kecamatan Seram Utara, Kecamatan Teluk Elpaputih, Kecamatan Seram Utara Barat dan Kecamatan Leihitu Barat.

Jika dilihat dari Tabel 6 nilai LQ yang berada diatas 1 pada tahun 2008-2010 terdapat 9 Kecamatan yang memiliki nilai LQ > 1 atau sekitar 64,29 persen dari total Kecamatan, ini berarti bahwa Kabupaten Maluku Tengah terspesialisai secara lebih pada sektor ini. Sedangkan 5 Kecamatan lain yang memiliki nilai LQ $<1$, diantaranya 
Kecamatan Banda, Kecamatan Tehoru, Kecamatan TNS, Kecamatan Amahai dan Kecamatan Nusalaut.

Tabel 6. Nilai LQ Sektor Perdagangan, Hotel dan Restoran Menurut Kecamatan di Kabupaten Maluku Tengah Tahun $2008-2010$

\begin{tabular}{llll}
\hline \multicolumn{1}{c}{ Kecamatan } & $\mathbf{2 0 0 8}$ & $\mathbf{2 0 0 9}$ & $\mathbf{2 0 1 0}$ \\
\hline Banda & 0,77 & 0,80 & 0,88 \\
Tehoru & 0,90 & 0,91 & 0,92 \\
Amahai & 0,46 & 0,45 & 0,47 \\
Kota Masohi & 1,39 & 1,39 & 1,36 \\
TNS & 0,57 & 0,57 & 0,58 \\
Saparua & 1,08 & 1,08 & 1,08 \\
Nusalaut & 0,48 & 0,47 & 0,46 \\
Pulau Haruku & 1,25 & 1,24 & 1,22 \\
Salahutu & 1,10 & 1,07 & 1,04 \\
Leihitu & 1,03 & 1,03 & 1,00 \\
Seram Utara & 1,03 & 1,03 & 1,08 \\
Teluk Elpaputih & 1,18 & 1,18 & 1,19 \\
Seram Utara Barat & 1,15 & 1,13 & 1,11 \\
Leihitu Barat & 1,56 & 1,53 & 1,51 \\
\hline
\end{tabular}

Sumber : Data BPS Diolah

\section{$L Q$ Sektor Pengangkutan dan Komunikasi}

Tabel 7. Nilai LQ Sektor Pengangkutan dan Komunikasi Menurut Kecamatan di Kabupaten Maluku Tengah Tahun $2008-2010$

\begin{tabular}{lccc}
\hline \multicolumn{1}{c}{ Kecamatan } & $\mathbf{2 0 0 8}$ & $\mathbf{2 0 0 9}$ & $\mathbf{2 0 1 0}$ \\
\hline Banda & 1,41 & 1,39 & 1,35 \\
Tehoru & 0,72 & 0,72 & 0,74 \\
Amahai & 0,70 & 0,70 & 0,70 \\
Kota Masohi & 0,94 & 0,91 & 0,89 \\
TNS & 1,33 & 1,33 & 1,34 \\
Saparua & 1,06 & 1,05 & 1,06 \\
Nusalaut & 0,60 & 0,61 & 0,63 \\
Pulau Haruku & 1,06 & 1,06 & 1,10 \\
Salahutu & 1,85 & 1,92 & 1,92 \\
Leihitu & 0,71 & 0,70 & 0,71 \\
Seram Utara & 0,68 & 0,68 & 0,67 \\
Teluk Elpaputih & 1,61 & 1,62 & 1,65 \\
Seram Utara Barat & 0,76 & 0,75 & 0,76 \\
Leihitu Barat & 1,31 & 1,32 & 1,37 \\
\hline
\end{tabular}

Sumber : Data BPS Diolah

Jika dilihat dari nilai LQ dapat diketahui bahwa meskipun Sektor Pengangkutan dan Komunikasi didominasi oleh Kecamatan Salahutu, Kecamatan Amahai dan Kecamatan Kota Masohi tidak berarti bahwa ketiga Kecamatan ini memiliki Keunggulan Komparatif atau terspesialisasi secara berlebihan pada sektor ini. Hal ini dapat dilihat dari nilai LQ Kecamatan Kota Masohi dan Kecamatan Amahai yang kurang dari 1. Tepatnya nilai
LQ sektor Pengangkutan dan Komunikasi berturut-turut sebesar 0,89 dan 0,70 .

Jika dilihat dari tabel 7 , Nilai LQ $>1$ pada tahun 2008-2010 terdapat pada 7 kecamatan, diantaranya : Kecamatan Banda, Kecamatan Saparua, Kecamatan Pulau Haruku, Kecamatan Salahutu, Kecamatan TNS, Kecamatan Teluk Elpaputih dan Kecamatan Leihitu Barat. Nilai LQ yang terbesar pada Kecamatan Salahutu ini menandakan bahwa Kecamatan Salahutu memiliki spesialisasi berlebih pada sektor ini, sehingga dapat dikatakan bahwa Kecamatan Salahutu memiliki Keunggulan pada sektor Pengangkutan dan Komunikasi. Sedangkan yang memiliki nilai LQ yang terkecil adalah pada Kecamatan Nusalaut 0,63 diikuti dengan Kecamatan Seram Utara sebesar 0,67.

\section{$L Q$ Sektor Keuangan, Persewaan dan Jasa Perusahaan}

Tabel 8. Nilai LQ Sektor Keuagan, Persewaan dan Jasa Perusahaan Menurut Kecamatan di Kabupaten Maluku Tengah Tahun $2008-2010$

\begin{tabular}{lccc}
\hline \multicolumn{1}{c}{ Kecamatan } & $\mathbf{2 0 0 8}$ & $\mathbf{2 0 0 9}$ & $\mathbf{2 0 1 0}$ \\
\hline Banda & 0,41 & 0,41 & 0,39 \\
Tehoru & 0,62 & 0,64 & 0,62 \\
Amahai & 0,90 & 0,91 & 0,89 \\
Kota Masohi & 2,25 & 2,20 & 2,19 \\
TNS & 0,23 & 0,24 & 0,24 \\
Saparua & 0,46 & 0,46 & 0,45 \\
Nusalaut & 0,21 & 0,22 & 0,22 \\
Pulau Haruku & 0,15 & 0,15 & 0,15 \\
Salahutu & 0,86 & 0,86 & 0,86 \\
Leihitu & 0,33 & 0,33 & 0,33 \\
Seram Utara & 0,22 & 0,22 & 0,21 \\
Teluk Elpaputih & 0,32 & 0,34 & 0,33 \\
Seram Utara Barat & 0,26 & 0,26 & 0,26 \\
Leihitu Barat & 0,66 & 0,68 & 0,68 \\
\hline
\end{tabular}

Sumber : Data BPS Diolah

Kecamatan Kota Masohi merupakan satu-satunya Kecamatan di Kabupaten Maluku Tengah yang memiliki nilai LQ yang lebih besar dari 1. Ini menandakan bahwa Kecamatan Kota Masohi memiliki spesialisasi berlebihan pada sektor ini. Sedangkan 13 Kecamatan Lainnya nilai LQ berada di bawah 1. Jadi dapat dikatakan bahwa hanya Kecamatan Kota Masohi yang memiliki keunggulan pada sektor ini.

\section{$L Q$ Sektor Jasa-jasa}

Tidak jauh berbeda dengan dengan sektor tersier lainnya, sektor jasa-jasa juga didominasi oleh Kecamatan Kota Masohi, Kecamatan Amahai dan Kecamatan Salahutu dimana Nilai Tambah yang diberikan dari ketiga sektor ini hampir mencapai 70 persen. Nilai Tambah dari Kecamatan Kota Masohi merupakan yang terbesar sebagai kontributor pada sektor Jasa-Jasa sebesar 36,81 persen; diikuti dengan Kecamatan Amahai dengan 
kontribusi sebesar 17,91 persen dan Kecamatan Salahutu dengan kontribusi sebesar 13,01 persen. Sedangkan Kontribusi yang paling kecil diberikan oleh Kecamatan Leihitu Barat sebesar 1,21 persen.

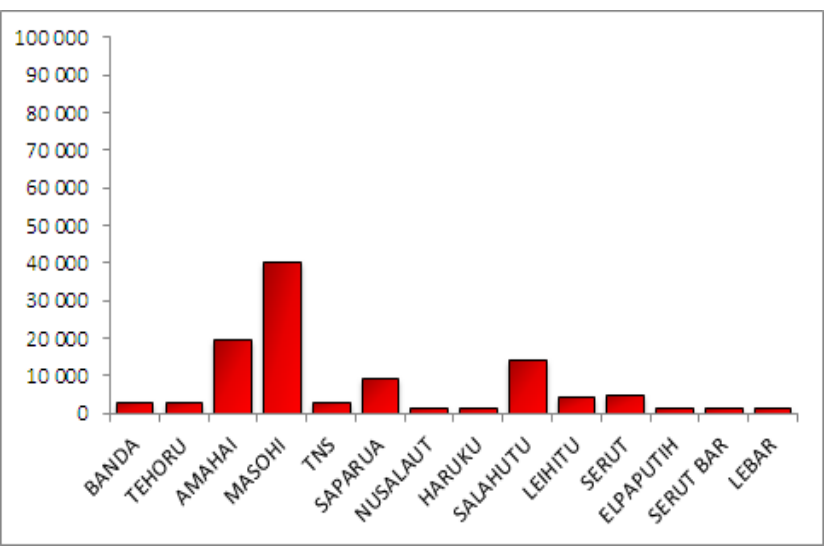

Sumber: BPS Kabupaten Maluku Tengah, 2011

Gambar 3. Nilai Tambah Sektor Jasa-jasa menurut Kecamatan di Kabupaten Maluku Tengah Tahun 2010 (Juta Rupiah)

Tabel 9. Nilai LQ Sektor Jasa-jasa Menurut Kecamatan di Kabupaten Maluku Tengah Tahun 2008 - 2010

\begin{tabular}{lccc}
\hline \multicolumn{1}{c}{ Kecamatan } & $\mathbf{2 0 0 8}$ & $\mathbf{2 0 0 9}$ & $\mathbf{2 0 1 0}$ \\
\hline Banda & 0,45 & 0,46 & 0,45 \\
Tehoru & 0,42 & 0,43 & 0,44 \\
Amahai & 0,94 & 0,95 & 1,00 \\
Kota Masohi & 1,63 & 1,59 & 1,55 \\
TNS & 1,01 & 1,04 & 1,04 \\
Saparua & 1,45 & 1,45 & 1,44 \\
Nusalaut & 0,88 & 0,91 & 0,93 \\
Pulau Haruku & 0,44 & 0,46 & 0,46 \\
Salahutu & 1,08 & 1,08 & 1,05 \\
Leihitu & 0,53 & 0,53 & 0,54 \\
Seram Utara & 0,67 & 0,67 & 0,65 \\
Teluk Elpaputih & 0,53 & 0,54 & 0,54 \\
Seram Utara Barat & 0,97 & 0,98 & 0,97 \\
Leihitu Barat & 0,73 & 0,75 & 0,76 \\
\hline
\end{tabular}

Sumber : Data BPS Diolah

Ditinjau dari besarnya nilai LQ Sektor Jasa - Jasa maka Kecamatan di Kabupaten Maluku Tengah terbagi atas tiga kelompok yaitu :

- Kelompok yang memiliki nilai LQ $<1$, Kecamatan yang termasuk dalam kelompok ini adalah Kecamatan Banda, Kecamatan Tehoru, Kecamatan Nusalaut, Kecamatan Pulau Haruku, Kecamatan Leihitu, Kecamatan Seram Utara, Kecamatan Teluk Elpaputih, Kecamatan Seram Utara Barat dan Kecamatan Leihitu Barat (2010). Ini berarti bahwa Kecamatan tersebut relatif tidak memiliki nilai komparatif/keunggulan komparatif pada Sektor Jasa-Jasa.
- Kelompok yang memiliki nilai $L Q=1$. Jika nilai LQ suatu daerah sebesar 1 maka dapat dikatakan bahwa daerah yang bersangkutan tidak terspesialisasi secara berlebihan ataupun kurang pada aktivitas ekonomi yang dimaksud. Pada tahun 2010 terdapat Kecamatan Amahai yang masuk dalam kelompok ini.

- Kelompok yang memiliki nilai LQ > 1. Kecamatan yang memiliki nilai LQ $>1$ adalah Kecamatan Kota Masohi, Kecamatan TNS, Kecamatan Saparua dan Kecamatan Salahutu. Kecamatan yang termasuk dalam kategori ini dapat dikatakan bahwa Kecamatan tersebut adalah Kecamatan yang relatif terspesialisasi secara berlebihan (overspecialized) pada aktivitas ekonomi (sektor) yang bersangkutan. Atau dapat juga dikatakan bahwa daerah tersebut memiliki keunggulan pada Sektor Jasa-Jasa.

\section{B. Analisis Shift-Share}

Tabel 10. Nilai Regional Share Menurut Sektor dan Kecamatan di Kabupaten Maluku Tengah Tahun 2008 - 2010

\begin{tabular}{lrrrrrrrrr}
\hline \multicolumn{1}{c}{ Kecamatan } & \multicolumn{1}{l}{$\mathbf{2}$} & \multicolumn{1}{l}{$\mathbf{3}$} & \multicolumn{1}{l}{$\mathbf{5}$} & \multicolumn{1}{c}{$\mathbf{6}$} & $\mathbf{7}$ & $\mathbf{8}$ & \multicolumn{1}{c}{$\mathbf{9}$} \\
\hline Banda & 187 & 2 & -519 & -1 & -1 & 1.383 & -47 & -20 & 58 \\
Tehoru & -420 & -7 & -243 & -2 & -63 & -259 & -25 & -58 & -19 \\
Amahai & 699 & 93 & -1.321 & 3 & 2 & 223 & -37 & -110 & 944 \\
Kota Masohi & 166 & 4 & 1.673 & 24 & 637 & 1.778 & -69 & 333 & 23 \\
TNS & -454 & -2 & -109 & -5 & -26 & -119 & -7 & -5 & -107 \\
Saparua & -84 & -8 & -141 & -12 & -108 & -74 & -18 & -17 & -135 \\
Nusalaut & -223 & -1 & -154 & -2 & -18 & -157 & -7 & -4 & -40 \\
Pulau Haruku & -181 & -3 & -517 & -2 & -77 & -723 & -46 & -5 & -52 \\
Salahutu & -123 & -41 & 1.903 & 6 & -107 & -1.262 & 336 & -19 & -404 \\
Leihitu & 318 & -17 & -532 & -3 & -86 & -781 & -12 & -33 & -13 \\
Seram Utara & 89 & 2 & 17 & -4 & -149 & 838 & -27 & -13 & -107 \\
T. Elpaputih & -90 & -18 & -24 & -1 & -4 & -227 & -15 & -35 & -49 \\
SUB & 168 & 0 & -4 & -2 & 0 & -197 & -12 & -3 & -58 \\
Leihitu Barat & -53 & -6 & -29 & 1 & -1 & -423 & -15 & -11 & -41 \\
\hline
\end{tabular}

Sumber : Data BPS Diolah

Tabel 11. Nilai National Share Menurut Sektor dan Kecamatan di Kabupaten Maluku Tengah Tahun 2008 - 2010

\begin{tabular}{lrrrrrrrrr}
\hline Kecamatan & \multicolumn{1}{c}{$\mathbf{1}$} & \multicolumn{1}{c}{$\mathbf{3}$} & \multicolumn{1}{c}{$\mathbf{4}$} & $\mathbf{5}$ & $\mathbf{6}$ & $\mathbf{7}$ & $\mathbf{8}$ & \multicolumn{1}{c}{} \\
\hline Banda & 1.417 & 3 & 536 & 5 & 53 & 757 & 266 & 66 & 274 \\
Tehoru & 1.921 & 11 & 252 & 7 & 57 & 1.018 & 156 & 171 & 294 \\
Amahai & 5.331 & 89 & 980 & 68 & 214 & 1.448 & 422 & 468 & 1.832 \\
Kota Masohi & 571 & 0 & 578 & 128 & 719 & 5.453 & 712 & 1.456 & 3.940 \\
TNS & 801 & 2 & 164 & 6 & 14 & 258 & 29 & 17 & 284 \\
Saparua & 467 & 8 & 650 & 19 & 68 & 1.099 & 207 & 77 & 908 \\
Nusalaut & 483 & 0 & 147 & 2 & 10 & 137 & 32 & 10 & 154 \\
Pulau Haruku & 671 & 6 & 340 & 7 & 39 & 782 & 128 & 15 & 171 \\
Salahutu & 1.751 & 66 & 594 & 48 & 78 & 2.372 & 765 & 306 & 1.433 \\
Leihitu & 1.218 & 47 & 1.177 & 23 & 53 & 1.376 & 180 & 73 & 438 \\
Seram Utara & 1.785 & 9 & 374 & 14 & 92 & 1.277 & 163 & 45 & 513 \\
T. Elpaputih & 700 & 21 & 20 & 1 & 2 & 625 & 163 & 115 & 174 \\
SUB & 401 & 2 & 4 & 2 & 1 & 311 & 40 & 11 & 163 \\
Leihitu Barat & 282 & 12 & 23 & 0 & 1 & 460 & 74 & 32 & 133 \\
\hline
\end{tabular}

Sumber : Data BPS Diolah

Regional Share/Competitive Effect (R) menggambarkan bagaimana jika sektor didaerah objek tersebut tumbuh seperti pola pertumbuhan sektor yang sama di Kabupaten pembanding.

- Jika hasil $\mathrm{R}$ adalah positif dan lebih kecil dari pertumbuhan aktual sektor tersebut didaerah objek yang diteliti maka secara relatif Kabupaten pembanding lebih unggul dari daerah objek yang bersangkutan.

- Jika hasil $\mathrm{R}$ adalah positif dan lebih besar dari pertumbuhan aktual sektor tersebut didaerah objek 
yang diteliti maka secara relatif daerah objek yang diteliti/bersangkutan lebih baik dari pada Kabupaten pembanding.

- Jika hasil $\mathrm{R}$ adalah negatif maka dapat dikatakan provinsi pembanding adalah lebih unggul secara absolut pada sektor yang bersangkutan dibandingkan dengan daerah objek yang diamati.

National Share/National Growth Effect (N) merupakan pertumbuhan daerah dibandingkan dengan pertumbuhan Kabupaten dari Kabupaten tertentu.

- Jika sektor tertentu pada Kabupaten tersebut memiliki pertumbuhan yang positif maka Nilai $\mathrm{N}$ untuk daerah objek yang dianalisis akan positif.

- Jika sektor tertentu Kabupaten tersebut memiliki pertumbuhan negatif maka nilai $\mathrm{N}$ untuk daerah objek yang dianalisis akan negatif juga.

Tabel 12. Nilai Propotional Shift Menurut Sektor dan Kecamatan di Kabupaten Maluku TengahTahun 2008 - 2010

\begin{tabular}{lcrrrrrrrr}
\hline \multicolumn{1}{c}{ Kecamatan } & \multicolumn{1}{c}{$\mathbf{2}$} & \multicolumn{1}{c}{$\mathbf{3}$} & \multicolumn{1}{c}{$\mathbf{4}$} & $\mathbf{5}$ & $\mathbf{6}$ & $\mathbf{7}$ & $\mathbf{8}$ & $\mathbf{9}$ \\
\hline Banda & -649 & 2 & 256 & -5 & 161 & 116 & 33 & -20 & -26 \\
Tehoru & -879 & 9 & 120 & -6 & 172 & 156 & 19 & -52 & -28 \\
Amahai & -2441 & 73 & 467 & -60 & 650 & 222 & 52 & -143 & -175 \\
Kota Masohi & -261 & 0 & 276 & -113 & 2.183 & 835 & 88 & -445 & -376 \\
TNS & -367 & 2 & 78 & -5 & 42 & 40 & 4 & -5 & -27 \\
Saparua & -214 & 6 & 310 & -17 & 207 & 168 & 26 & -23 & -87 \\
Nusalaut & -221 & 0 & 70 & -2 & 31 & 21 & 4 & -3 & -15 \\
Pulau Haruku & -307 & 5 & 162 & -7 & 119 & 120 & 16 & -5 & -16 \\
Salahutu & -802 & 54 & 283 & -43 & 237 & 363 & 95 & -93 & -137 \\
Leihitu & -558 & 39 & 562 & -21 & 162 & 211 & 22 & -22 & -42 \\
Seram Utara & -817 & 8 & 178 & -13 & 280 & 195 & 20 & -14 & -49 \\
T. Elpaputih & -320 & 18 & 10 & -1 & 6 & 96 & 20 & -35 & -17 \\
SUB & -184 & 2 & 2 & -1 & 2 & 48 & 5 & -3 & -16 \\
Leihitu Barat & -129 & 10 & 11 & 0 & 3 & 70 & 9 & -10 & -13 \\
\hline
\end{tabular}

Sumber : Data BPS Diolah

Tabel 13. Nilai Perubahan Total Dalam Output Daerah Menurut Sektor dan Kecamatan di Kabupaten Maluku Tengah Tahun $2008-2010$

\begin{tabular}{lrrrrrrrrr}
\hline Kecamatan & \multicolumn{1}{c}{$\mathbf{2}$} & \multicolumn{1}{c}{$\mathbf{3}$} & $\mathbf{4}$ & $\mathbf{5}$ & $\mathbf{6}$ & $\mathbf{7}$ & $\mathbf{8}$ & $\mathbf{9}$ \\
\hline Banda & 955 & 6 & 273 & 0 & 213 & 2.256 & 251 & 26 & 306 \\
Tehoru & 622 & 13 & 128 & -1 & 166 & 915 & 150 & 60 & 246 \\
Amahai & 3.590 & 255 & 126 & 10 & 866 & 1.892 & 437 & 215 & 2.601 \\
Kota Masohi & 476 & 4 & 2.528 & 38 & 3.539 & 8.066 & 732 & 1.344 & 3.586 \\
TNS & 20 & 2 & 134 & 4 & 30 & 179 & 26 & 7 & 150 \\
Saparua & 169 & 6 & 819 & 10 & 167 & 1.193 & 215 & 36 & 686 \\
Nusalaut & 39 & 0 & 63 & 2 & 23 & 0 & 30 & 3 & 99 \\
Pulau Haruku & 183 & 8 & -14 & 1 & 82 & 179 & 98 & 5 & 102 \\
Salahutu & 827 & 79 & 2.780 & 11 & 208 & 1.473 & 1.196 & 193 & 892 \\
Leihitu & 978 & 69 & 1.207 & 1 & 129 & 805 & 191 & 18 & 383 \\
Seram Utara & 1.057 & 18 & 569 & 2 & 223 & 2.311 & 156 & 19 & 357 \\
T. Elpaputih & 290 & 21 & 5 & 1 & 5 & 494 & 168 & 44 & 108 \\
SUB & 386 & 5 & 1 & 2 & 2 & 162 & 32 & 5 & 89 \\
Leihitu Barat & 100 & 16 & 5 & 1 & 2 & 108 & 69 & 11 & 80 \\
\hline
\end{tabular}

Sumber : Data BPS Diolah

Proportional Shift/Sectoral Mix Effect/Composition Shift (M) adalah merupakan efek dari perbedaan pertumbuhan sektoral yang diamati pada suatu Kabupaten pembanding terhadap pertumbuhan total Kabupaten tersebut.

- Jika sektor yang dibandingkan tumbuh lebih tinggi daripada pertumbuhan total pertumbuhan di
Kabupaten pembanding maka hasilnya akan positif sehingga nilai $\mathrm{M}$ untuk sektor tersebut didaerah objek yang diteliti akan menjadi positif.

- Jika sektor yang dibandingkan tumbuh lebih rendah daripada pertumbuhan total pertumbuhan di Kabupaten pembanding maka hasilnya akan negatif sehingga nilai $\mathrm{M}$ untuk sektor tersebut didaerah objek yang diteliti akan menjadi negatif.

\section{KESIMPULAN}

Berdasarkan pembahasan sebelumnya dapat disimpulkan beberapa hal yang berkaitan dengan Analisis Pemanfaatan Potensi Daerah Di Kabupaten Maluku Tengah antara lain:

1. Kecamatan Banda Relatif memiliki spesialisasi secara berlebihan (overspecialized) pada aktivitas ekonomi : Sektor Pertanian dan Sektor Perdagangan, Hotel dan Restoran (2008-2010).

2. Kecamatan Tehoru dan Kecamatan Seram Utara memiliki Spesialisasi berlebihan pada sektor primer (sektor pertanian) pada tahun 2008-2010 dan Kecamatan ini merupakan Kecamatan tua.

3. Kecamatan Kota Masohi memiliki spesialisasi secara berlebihan (overspecialized) (Niali LQ > 1) pada aktifitas ekonomi (sektor) sebagai berikut : Listrik dan Air Bersih; Bangunan; Perdagangan, Hotel dan Restoran; Keuangan, Persewaan dan Jasa Perusahaan; dan Sektor Jasa-Jasa. Dari sini dapat dikatakan bahwa Kecamatan Kota Masohi terspesialisasi terutama pada sektor-sektor sekunder dan tersier.

\section{DAFTAR PUSTAKA}

[1] Badan Pusat Statistik Kabupaten Maluku Tengah. Pendapatan Domestik Regional Bruto Kabupaten Maluku Tengah 2008. Masohi. 2009.

[2] Badan Pusat Statistik Kabupaten Maluku Tengah. Pendapatan Domestik Regional Bruto Kabupaten Maluku Tengah 2009. Masohi. 2010.

[3] Badan Pusat Statistik Kabupaten Maluku Tengah. Pendapatan Domestik Regional Bruto Kabupaten Maluku Tengah 2010. Masohi. 2011.

[4] Badan Pusat Statistik Provinsi Maluku. Analisis Pemanfaatan Potensi Daerah Di Provinsi Maluku Tahun 2006-2008. Ambon. 2009.

[5] Kuncoro, Mudrajad. Metode Kuantitatif, Teori dan Aplikasi Untuk Bisnis dan Ekonomi. UPP STIM YKPN. Yogyakarta. 2007.

[6] Urai, Nursinah A. 1999. Kesenjangan Pemanfaatan Potensi Daerah. BPS. Jakarta. 